\title{
Evolution of structure and activity of char-supported iron catalysts prepared for steam reforming of bio-oil
}

Yi Wang a,b, Long Jiang a, ${ }^{*}$, Song Hu a, b, Sheng Su a, b, Yingbiao Zhou a, Jun Xiang a, b, Shu Zhang c, Chun-Zhu Lic

a. State Key Laboratory of Coal Combustion, School of Energy and Power Engineering, Huazhong University of Science and Technology, Wuhan 430074, China

b. China-EU Institute for Clean and Renewable Energy at Huazhong University of Science and Technology, Wuhan 430074, China;

c. Fuels and Energy Technology Institute, Curtin University of Technology, GPO Box U1987, Perth, Western Australia 6845, Australia

*Corresponding author: Long Jiang, E-mail:jianglong@hust.edu.cn; Address: Room 504, State Key Laboratory of Coal Combustion, Huazhong University of Science and Technology, 1037 Luoyu Road, Wuhan 430074, P. R. China

\begin{abstract}
The aim of this study is to investigate the changes in iron phase, crystal size, surface area, and char structure/reactivity of the char-supported iron catalysts after them being used for bio-oil reforming. The catalysts were prepared under different conditions (varying in temperatures, gasification agents and iron concentrations) and then used to reform bio-oil under a fixed experimental condition at $800{ }^{\circ} \mathrm{C}$. The results show that the catalysts prepared from the steam gasification of Fe-loaded coal were preferred in terms of catalytic performance. The X-ray diffraction analysis indicates that the iron phases in the fresh catalysts varied while the used catalysts nearly showed identical iron phase of magnetite $\left(\mathrm{Fe}_{3} \mathrm{O}_{4}\right)$. The crystal iron particle in the catalysts would apparently increase after reforming when the initial iron phase was carbides ( $\gamma$-Fe and/or $\alpha-F e)$. The char structure of the catalysts was significantly affected by the 'volatile-char interactions' during reforming process. And the catalysts' surface area and reactivity in air were both reduced mainly due to the coke formation.
\end{abstract}

Keywords: bio-oil; catalytic reforming; char-supported iron catalyst; char structure; volatile-char interaction 


\section{Introduction}

Biomass gasification is one of the most promising routes to produce syngas $[1,2]$. However, there are a number of technical barriers that need to be overcome to further develop a more advanced biomass gasification technology. The most challenging one is the presence of tarry by-products in the product gas, which has the potential to cause severe blocking and fouling problems in downstream applications and deactivate catalysts in the downstream synthesis process [3-5].

To date, numerous tar elimination techniques, such as thermal cracking, physical capture, catalytic reforming, plasma cracking etc., have been exploited [6, 7]. Among these techniques, catalytic tar reforming has been believed widely as a technically and economically feasible method to convert tar into light gas [8-12]. Recently, char/char-supported catalysts, which have the below advantages: ( i ) inexpensive and easily available due to the easy and abundant production of char from coal/biomass pyrolysis; (ii) the spent catalyst can be directly/simply gasified/burned to recover the char's energy without any additional regeneration and disposal, have been widely reported as a promising medium to substantially reform/crack tar into light gases and coke $[4,11$, 13-15]. It is a technically and economically interesting approach for gas cleaning.

Previous studies $[11,16]$ pointed out the char loaded with some catalytically active species showed much higher reactivity for tar reforming than the char itself. The transition metal of iron is believed as an attractive catalytically active species of char-supported catalyst to reform tar during the gasification of biomass by reasons of its high economic feasibility, adequate catalytic activities and non-toxicity $[16,17]$.

Numbers of literatures have reported the performance and activity of the char-supported iron catalysts (CSICs) [15, 17-20], and the results show that the CSICs exhibit sufficient activity for tar reforming during gasification of biomass. Clearly, the activity of the CSICs is influenced significantly by the parameters such as char structure, char reactivity, catalytic species phase etc. These parameters further depend on preparation conditions (especially temperature and reactive atmosphere). However, only a few studies have been found to focus on the relationship between the above parameters changes and catalytic activity of CSICs. Min et al. [21] investigated the bio-char structure changes of the 
CSICs during steam reforming of tar, but the temperature and reactive atmosphere in catalysis preparation were not involved in. Further investigations focusing on the above aspects are vital to an in-depth insight into understanding the catalytic mechanism of the char-supported catalysts during the catalytic reforming process.

This study aims at investigating the evolution of char structure and catalytic species phase in the CSIC during bio-oil steam reforming. CSICs were firstly prepared under different temperature and reactive atmosphere. Following reforming tar/bio-oil, the changes in iron phase/crystal size, char physicochemical structure and char reactivity were examined to understand the relationship between the above parameters changes and catalytic performance of CSICs.

\section{Experimental}

\subsection{Catalyst Preparation.}

A sub-bituminous coal mined from Zhundong coalfield, which is the largest intact coalfield in China newly discovered in the east of Junggar Basin, Xinjiang, China, was firstly ground and sieved to the particle diameter of 106 150 $\mu \mathrm{m}$, and then air-dried in an oven at the temperature of $105^{\circ} \mathrm{C}$ for 24 hours used for this experiment. The proximate and ultimate analysis results and ash compositions of the coal sample are presented in Table 1.

The sieved coal sample was added into a $0.2 \mathrm{M}$ sulphuric acid solution (the ratio of coal and acid solution is 1:30 by mass) and stirred in a nitrogen atmosphere for $24 \mathrm{~h}$ to eliminate minerals influence in coal. Then it was filtered and washed by de-ionized water until the sulphate ion could not be found (by the method of barium ion titration). The solid residue was finally dried using an oven at $105^{\circ} \mathrm{C}$ for 24 hours. The pre-treated coal sample was free of inorganic minerals due to transformation of all carboxylates (-COOM) into acids $(-\mathrm{COOH})$, and it is named as the H-form coal [17].The H-form coal was then respectively ion-exchanged with $1 \mathrm{wt} \%$ and $3 \mathrm{wt} \% \mathrm{FeCl}_{3}$ solution, and it is termed as the Fe-loaded coal.

The installation for slow pyrolysis of the Fe-loaded coal has been described elsewhere [22]. The detailed procedure was as follow: In each experiment, about $10 \mathrm{~g}$ of Fe-loaded coal was firstly loaded on quartz wool which was placed on the reactor's flaring. The nitrogen (flow rate of $500 \mathrm{ml} / \mathrm{min}$, purity $>99.999 \%$ ) was introduced into the reactor to eliminate impurities. Then the reactor was heated at $10^{\circ} \mathrm{C} / \mathrm{min}$ to the different desired temperature 
$\left(700,800\right.$ and $\left.900^{\circ} \mathrm{C}\right)$, thereafter held for $15 \mathrm{~min}$ at the desired temperature with gasification agent supply of pure $\mathrm{CO}_{2} / 30$ vol. \% steam/ 0.15 vol. \% $\mathrm{O}_{2}$. After the 15 min holding time, the gas was switched to the nitrogen, and the reactor was moved out of the furnace to be naturally cooled down at ambient temperature. The prepared CSIC was finally collected and sealed in desiccators for the following reforming experiment use.

\subsection{Reforming Experiments.}

The bio-oil used in the current study was derived from fast pyrolysis of $\mathrm{HCl}$ washed rice straw (harvested at Wuhan area, Hubei province, particle size between 125 and $210 \mu \mathrm{m}$ ) at temperature of $500^{\circ} \mathrm{C}$ with the similar procedure described elsewhere [23].The only difference is that the tar traps were not filled with an adsorption solvent, and they were all cooled using dry ice bath $\left(\sim-78.5^{\circ} \mathrm{C}\right)$. The ultimate analysis results of the bio-oil are: $\mathrm{C}$, 36.63; H, 7.67; N, 0.32; $\mathrm{S}, 0.03 ; \mathrm{O}, 53.35$ (wt \%, O is calculated by difference). The water content and the high heating value are $31.53 \mathrm{wt} \%$ and $17.52 \mathrm{MJ} / \mathrm{kg}$, respectively.

The bio-oil reforming was conducted in a laboratory-scale dual quartz reactor system which was used for pyrolysis/catalytic reforming of biomass/bio-oil in other studies [17, 24]. Briefly, the bottom of the reactor was used as a fluidised-bed pyrolyzer while the top of the reactor acted as a fixed-bed reformer laying catalyst.

The syringe pump was used to control the feeding of oil $(0.1 \mathrm{~g} / \mathrm{min})$ into the fluidised sand bed. Excess steam (feeding rate of $0.15 \mathrm{~g} / \mathrm{min}$ water $(\sim 250 \mathrm{ml} / \mathrm{min})$ controlled by a high performance liquid chromatography (HPLC) pump) was introduced at the middle of the dual reactors.

In each reforming experiment, accurately weighed $1 \pm 0.05 \mathrm{~g}$ of catalyst was pre-loaded in the top of the reactor, and this top part was always maintained at $800^{\circ} \mathrm{C}$ during feeding of the bio-oil. The bottom part was kept at $500{ }^{\circ} \mathrm{C}$ in order to pyrolysis of the bio-oil. Thus, pyrolysis and reforming of bio-oil were performed simultaneously. The resulting tar was subsequently captured using three tar traps filled a mixture of methanol and HPLC-grade chloroform (1:4, by volume) cooled using dry ice bath in the downstream tar capture system, which was previously described elsewhere [23, 25].

2.3. Tar analysis.

The methods of tar yield quantification and tar characterization were previously used 
elsewhere [23, 25]. Briefly, about $2 \mathrm{ml}$ of tar solution, which was weighed accurately, was dried at $35^{\circ} \mathrm{C}$ for 4 hours to evaporate the solvent and water completely to determine the concentration of tar. Then the tar yield can be calculated since the weight of the trapped solution was known.

The procedure of the tar characterization using ultraviolet-fluorescence spectroscopy was briefly described as follow: The tar solution, which was firstly diluted to 4 ppm (by weight) using HPLC-grade methanol to eliminate the self-absorption effects, was tested on an Agilent Cary Eclipse spectrometer to obtain the spectra. The constant energy difference was $1400 \mathrm{~cm}^{-1}$ and the scan speed was $200 \mathrm{~nm} / \mathrm{min}$. The light slit widths and light path lengths were respectively $2.5 \mathrm{~nm}$ and $1 \mathrm{~cm}$. Each spectrum was the mean of three scans. The fluorescence intensity displayed herein was calculated by multiplying the tar yield (on the basis of "per gram of bio-oil") [23, 25]

\subsection{Char Characterization}

\subsubsection{Iron phase}

The catalysts before and after reforming experiments were all characterized using X-ray diffraction (XRD). They were scanned on a PANalytical B.V. X' Pert PRO X-ray diffractometer $(\mathrm{Cu} \mathrm{Ka}, 40 \mathrm{kV}, 40 \mathrm{~mA})$. The XRD spectra were recorded in a scan range of $2 \theta=10^{\circ} \sim 70^{\circ}$.

\subsubsection{Char structure}

The chars' Raman spectra were recorded by using a Bruker VERTEX 70, and the detailed procedure was described elsewhere [26]. Briefly, an InGaAs detector cooled by liquid nitrogen was used to collect Raman scattering. The laser power was $400 \mathrm{~mW}$ and the excitation laser wavelength was $1064 \mathrm{~nm}$. Each spectrum was the mean of 512 scans while the resolution was $4 \mathrm{~cm}^{-1}$. To reduce the thermal emission of the samples, char was mixed with $\mathrm{KBr}(0.25 \%$ char in $\mathrm{KBr}$, spectroscopic grade) and ground manually. The Raman spectra $\left(800 \sim 1800 \mathrm{~cm}^{-1}\right)$ were curve-fitted with ten Gaussian bands demonstrating the typical structural features according to the methodology previously proposed by Li et al. [27-29]. And the detailed assignment of the main bands $\left(G, G_{R}, V_{L}, V_{R}, D\right.$ and $\left.S\right)$ can be found in Ref.[27-29].

\subsubsection{Char reactivity}


The reactivity of chars was determined in air at a temperature of $400{ }^{\circ} \mathrm{C}$ using a NETZSCH STA 449 F3 thermogravimetric analyser (TGA), and the detailed procedure was described previously [30]. Briefly, in each run, $4 \pm 0.2 \mathrm{mg}$ of char sample was loaded. The TG furnace was purged with high purity $\mathrm{N}_{2}$ three times to remove impurities, and it was then heated to $110{ }^{\circ} \mathrm{C}$ under $\mathrm{N}_{2}$ atmosphere (heating rate was $20^{\circ} \mathrm{C} / \mathrm{min}$ ), and this temperature was maintained for 30 min to completely eliminate the adsorbed $\mathrm{H}_{2} \mathrm{O}$ from the char. Consequently, the temperature was then increased to $400{ }^{\circ} \mathrm{C}$ (at a rate of $50{ }^{\circ} \mathrm{C} / \mathrm{min}$ ). After holding for about $2 \mathrm{~min}$, the atmosphere of $\mathrm{N}_{2}$ was switched to air. The reason for choosing the temperature of $400{ }^{\circ} \mathrm{C}$ was to minimize the effect of thermal annealing on chars in order to maintain their structure before reactivity measurement and also to avoid ignition when switching to air. After enough char conversion at $400{ }^{\circ} \mathrm{C}$, the temperature was elevated to $600{ }^{\circ} \mathrm{C}$ to completely combust the residual carbon (holding time was 30 min). The final mass was then taken as the mass of ash. The char's specific reactivity was calculated by the following equation:

$$
R=-\frac{1}{W} \frac{d W}{d t}
$$

where $\mathrm{R}$ represents the char's specific reactivity, $\mathrm{W}$ represents the char's dry and ash free basis mass at any given time.

\subsubsection{Surface area.}

The Brunauer-Emmett-Teller (BET) method was used to measure the surface area of fresh and spent catalysts by a Micromeritics ASAP 2020 gas adsorption analyzer. The samples were degassed in vacuum at $120^{\circ} \mathrm{C}$ for $24 \mathrm{~h}$ before each measurement.

\section{Results and discussion}

3.1. The yield of char-supported catalysts.

Figure 1 shows the catalyst yields after the gasification of Fe-loaded Zhundong coal in different reactive atmosphere $\left(\mathrm{O}_{2}\right.$, steam and $\left.\mathrm{CO}_{2}\right)$ from 700 to $900{ }^{\circ} \mathrm{C}$. It is clearly shown that relative high catalysts (char) yields (more than 50\%) were achieved during the gasification at the slow heating rate. In order to obtain these yields at slow heating rate were mainly because of that the slow rupture of coal structure favouring the possible re-combination of the fragments to form char and significant secondary reactions facilitated the formation of soot/coke from condensation reactions. Further char conversion due to 
temperature increasing from 700 to $900^{\circ} \mathrm{C}$ was not significant in all cases. This minor decrease in char yields with temperature increasing from 700 to $900{ }^{\circ} \mathrm{C}$ should be due to the increased inertness of char structure. From the figure, it can be observed that the reactive atmosphere affected the extent of char conversion slightly. Three different gasification agents, 0.15 vol. $\% \mathrm{O}_{2}, 30$ vol. \% steam and pure $\mathrm{CO}_{2}$ were used separately. Clearly, the reactivity of char in $\mathrm{O}_{2}$ is much higher than that in steam and $\mathrm{CO}_{2}$. However, the quite low concentration of $\mathrm{O}_{2}$ meant that the supply of $\mathrm{O}_{2}$ was the reaction-rate-limiting step, which led to the high char yields, even higher than those in steam and $\mathrm{CO}_{2}$ particularly in the case of 3\% Fe-loaded coal. Moreover, the effect of increasing temperature on decreasing the char yields was slightly apparent in the case of 3\% Fe-loaded coal. Presumably catalytic effect of $3 \% \mathrm{Fe}$ in coal on the reactions of char-steam and char- $\mathrm{CO}_{2}$ should be slightly stronger than that of $1 \%$ Fe in coal.

\subsection{Performance of catalysts in bio-oil reforming process.}

The UV-fluorescence spectroscopy is often used to semi-quantitatively characterize the aromatic ring systems of tars after reforming $[17,24,25,31]$, therefore, the performance of the catalysts prepared under different conditions could be compared on the same basis of "per gram of bio-oil".

As shown in Figure 2, the feature of peaks was similar, indicating the similarity of aromatic ring systems in the tars after being reformed by different catalysts. The difference in the height of peaks indicated the varying extents of aromatic reduction by reforming. Obviously, the catalysts prepared from steam gasification at high temperatures showed better activity than others in reducing aromatic ring systems. This might because that during the preparation process, the reactions between steam and char could produce abundant $\mathrm{H}$ radicals. The $\mathrm{H}$ radicals were very reactive and mobile, and thus possibly penetrating into iron-containing char matrix and replacing them. The freed iron species would likely migrate out and well disperse on the surface of those miro/meso-pore systems. Clearly the well-dispersed iron species on the pore surface could favour its catalytic performance [25].

From the results, it also can be observed that the effects of the temperature for preparing catalysts on catalytic activity were not profound under the gasification of $\mathrm{O}_{2}$ and 
$\mathrm{CO}_{2}$. The effects of Fe concentration from $1 \%$ to $3 \%$ in coal were only clearly observed only from gasification in steam.

3.3. The changes in Iron phase and crystal size of the catalysts before and after reforming.

Figure 3 to 5 illustrated the XRD patterns of the catalysts prepared from the gasification in the atmosphere of $\mathrm{CO}_{2}, \mathrm{H}_{2} \mathrm{O}$ and $\mathrm{O}_{2}$ at different temperatures before and after reforming experiments. The peaks that were not labelled denoted " $\mathrm{M}$ " (magnetite $\left.\mathrm{Fe}_{3} \mathrm{O}_{4}\right)$.

From these figures, it is clearly shown that the main phase of fresh catalysts prepared from different gasification agents was different. Unexpectedly, $\gamma$-Fe and a-Fe were the main phase for the catalysts prepared from oxygen gasification. Oxygen is much more capable than steam and $\mathrm{CO}_{2}$ to oxidize iron. However, the very low concentration of oxygen $(0.15$ vol. \%) meant that there was no extra oxygen for iron as all of them could quickly react with char to form $\mathrm{CO}$ and $\mathrm{CO}_{2}$. Due to the lack of oxidants, any iron oxides would be quickly reduced by carbon at the temperatures. In the case of $\mathrm{CO}_{2}(99.999 \%$ by volume) and steam (30 vol. \%) gasification, the gasification agents were supplied in excess, which would create a continuous partial oxidative environment surrounding iron.

Compared with the XRD results of the fresh catalysts, the main phase in different spent catalysts was mostly the same, i.e. magnetite, which was in sharp contrast with the result in the Min et al. study where all used catalyst contained not only iron oxides but also metallic irons $[16,25]$.The feedstock for the present study was bio-oil while the previous one was the same amount of biomass. Therefore, the gas phase in the current study might be more oxidative and the catalyst surface could be fully absorbed / associated with O-containing groups. Once the reforming process was stopped, the metallic irons could be quickly oxidized by the O-containing groups in a very short time. In terms of catalytic reaction mechanism, the literatures [32-34] tended to agree that metallic species existing in the chars featured high catalytic activity than others (iron oxides). However, the fresh catalysts from oxygen gasification mostly contained $\gamma$-Fe and $\alpha-F e$, but failed to give high catalytic performance. In contrast, if the initial iron phase does any matter in this study, the iron phase of FeO seems to be important to positively affect the eventual catalytic efficiency, as shown in Figure 5. Probably, the middle valence of iron in $\mathrm{FeO}$ was advantageous as it 
could go in two directions: reduction and oxidation. The char with FeO from the gasification in $\mathrm{O}_{2}$ did not show good catalytic activity, implying that the char created by the gasification in $\mathrm{O}_{2}$ may not be very porous. Oxygen would consume carbonaceous material much less selective than steam did. Therefore, it is reasonable that the char prepared from the gasification in steam was more porous and with higher surface area. Indeed, the BET analysis shown in Table 2 did prove this. The surface area of the chars prepared from gasification in steam was ranged from 409.3 to $479.1 \mathrm{~m}^{2} / \mathrm{g}$ while the surface area for the chars from the gasification in oxygen was ranged from 338.9 to $375.1 \mathrm{~m}^{2} / \mathrm{g}$.

From Table 3, the iron crystal size in the catalysts prepared from oxygen gasification increased after the reforming experiments, which might be mainly due to the iron phase transform from $\gamma$-Fe or $\alpha-F e$ to magnetite $\left(\mathrm{Fe}_{3} \mathrm{O}_{4}\right)$. The iron crystal size slightly decreased for the catalysts prepared from the gasification in steam and $\mathrm{CO}_{2}$. As stated in Min et al. study [16], the possible iron particle agglomeration at high temperatures could have been inhibited by the supporting base-char. Additionally, the crystal iron particles in the fresh catalyst could likely transform to amorphous status after reforming bio-oil.

\subsection{The char structure evolution.}

The Figure 6 shows the total observed Raman peak area (intensity) of the fresh and used catalysts range from 800 to $1800 \mathrm{~cm}^{-1}$. The total Raman intensity is influenced by both the light absorptivity of the catalyst and the Raman scattering ability [28]. Electron-rich structures such as O-containing functional groups can indirectly increase the Raman intensity by exerting a resonance effect on aromatic ring systems [27, 28]. On the other hand, the aromatic ring systems condensation which could greatly improve light absorptivity results in a low total Raman intensity [27-29].

From Figure 6, the total observed Raman areas of different fresh catalysts decreased with increasing preparation temperature. This was due to the growth of aromatics as well as the loss of O-containing functional groups with enhanced thermal annealing effects.

The total observed Raman intensity for the spent catalyst samples showed a very similar value. The similar total observed Raman area for the used catalysts could not be explained by the reforming temperature of $800^{\circ} \mathrm{C}$. This could be apparently seen by comparing the total Raman area for the fresh char prepared at $800^{\circ} \mathrm{C}$ with itself after being 
used at the same temperature. Indeed, the organic vapour from the decomposition of bio-oil was forced to strongly interact with the char/catalyst bed in the specially-designed reactor to achieve the reforming target. The volatile-char interactions have been intensively studied in the former studies [35-38], which demonstrated that the interactions could dramatically alter char structure, AAEM contents and thus char reactivity. Therefore, the similar total Raman area indicated that the volatile-char interactions could probably play a dominant role for determining the char structure. In other words, the differences in char structure of the fresh catalysts have been removed after they were subjected to the same extent of char- volatile interactions.

The catalysts/chars prepared from the Zhundong coal exhibit the presence of both small and large aromatic ring systems. The large aromatic ring systems are principally represented by the $D$ band (larger than 6 fused benzene rings) while the $G_{R}, V_{L}$ and $V_{R}$ bands reflect the small aromatic ring systems (3-5 fused rings) [27, 28]. The ratio of the total intensities of $V_{R}, V_{L}$ and $G_{R}$ bands to the intensity of $D$ band thereby demonstrates the ratio of the aromatic ring systems to the large aromatic ring systems, which were typically discovered in amorphous carbon.

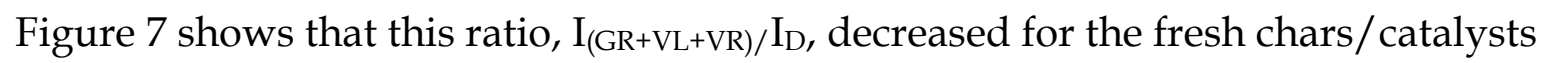
with increasing preparation temperature. This was understandable by considering enhanced ring condensation at high temperatures. The ratio was almost the same for the char after reforming reactions regardless of experimental conditions used for preparing the catalysts. As stated in experimental section, the same reforming conditions were used in all reforming experiments: identical temperature of $800^{\circ} \mathrm{C}$, the same supply of steam $(15 \%$ by volume), and the same extent of char-volatile interactions. These interactions might also play a key role in determining the final observed ratio. Abundant $\mathrm{H}$ radicals were generated from the thermal reforming/cracking of bio-oil volatiles by interacting with char/catalysts. The $\mathrm{H}$ radicals could penetrate the carbon matrix and induce the condensation of the aromatic ring systems.

\subsection{Reactivity in air.}

The catalysts' specific reactivity before and after reforming experiments were tested on a TGA in air atmosphere at the isothermal condition of $400{ }^{\circ} \mathrm{C}$, as shown in Figures 8-10. 
The reactivity of the fresh catalysts decreased with increasing preparation temperatures from 700 to $900^{\circ} \mathrm{C}$. The reactivity of the spent catalysts sharply dropped compared to the fresh ones.

The decrease in the relevant proportion of small to large aromatic ring systems (shown in Figure 7) was the main causes for the decrease in char/catalyst reactivity. Surely, the activation energy for the large fused aromatic ring systems was extremely larger than that of the small aromatic ring systems. In extreme condition, graphite-like structure could be very stable at the temperature of $400{ }^{\circ} \mathrm{C}$. In contrast, the lower char reactivity in spent catalysts than fresh ones resulted from not only the change in char structure discussed above, but also coke formation which reduced catalysts surface area significantly as shown in Table 3. Interestingly, the spent catalysts showed high specific reactivity in Min et al. study than the fresh one $[16,25]$. The key reason could be from the difference in the amount of reformed bio-oil. In Min's study, only 1 gram biomass was fed into the reactor and the produced volatiles then passed through the catalysts bed (1 gram) and were reformed. Contrastingly, $1 \mathrm{~g}$ bio-oil was continuously injected into the reactor to be reformed by the catalysts (1gram) prepared in this study. Therefore, the volatile-char interactions as well as the coke formation in the present study could be much more serious than the case reported in previous work.

\section{Conclusions}

CSICs were prepared from gasification in different reactive atmosphere $\left(0.15\right.$ vol. $\% \mathrm{O}_{2}$, steam or $\mathrm{CO}_{2}$ ) at different temperatures for the bio-oil reforming. The catalysts prepared from the gasification in steam showed a better activity possibly due to the better dispersion of iron species with $\mathrm{H}$ radicals involvement. XRD analysis did not agree that the metallic species showed better catalytic ability than others (iron oxides). Char structure characterised by FT-Raman indicates that the char-volatile interactions during the reforming reaction reduced the relative abundance of small aromatic ring systems. The drastic decrease in BET surface area of used catalysts due to serious coke formation took place during reforming, which fill the pores. The coke formation led to the drastic decrease in BET surface area of used catalysts. The change in char structure and surface area together contributed to the low char reactivity of the used catalysts prepared from all the conditions 
investigated above.

\section{Acknowledgement}

In this study, the authors greatly appreciate the financial support from the National Science Foundation of China (NSFC) (NO. 51506070, 51606080), Program for New Century Excellent Talents in University (NO. NCET-13-0226), the China Postdoctoral Science Foundation funded project (NO. 2014M552038) and Shanxi Science and Technology Major Project (MD 2015-03/05). They also acknowledge the testing service and help from the Analytical and Testing Center at Huazhong University of Science and Technology.

\section{Reference}

[1] G. Chen, J. Yao, H. Yang, B. Yan, H. Chen, Steam gasification of acid-hydrolysis biomass CAHR for clean syngas production, Bioresour. Technol. 179 (2015) 323-330.

[2] D. Yao, Q. Hu, D. Wang, H. Yang, C. Wu, X. Wang, H. Chen, Hydrogen production from biomass gasification using biochar as a catalyst/support, Bioresour. Technol. 216 (2016) 159-164.

[3] M. Artetxe, M.A. Nahil, M. Olazar, P.T. Williams, Steam reforming of phenol as biomass tar model compound over Ni/ Al2O3 catalyst, Fuel 184 (2016) 629-636.

[4] A.S. Al-Rahbi, J.A. Onwudili, P.T. Williams, Thermal decomposition and gasification of biomass pyrolysis gases using a hot bed of waste derived pyrolysis char, Bioresour. Technol. 204 (2016) 71-79.

[5] M. Keller, J. Fung, H. Leion, T. Mattisson, Cu-impregnated alumina/silica bed materials for Chemical Looping Reforming of biomass gasification gas, Fuel 180 (2016) 448-456.

[6] Y. Shen, Chars as carbonaceous adsorbents/catalysts for tar elimination during biomass pyrolysis or gasification, Renew. Sust. Energ. Rev. 43 (2015) 281-295.

[7] Z. Abu El-Rub, E.A. Bramer, G. Brem, Review of Catalysts for Tar Elimination in Biomass Gasification Processes, Ind. Eng. Chem. Res. 43 (2004) 6911-6919.

[8] D.H. Heo, R. Lee, J.H. Hwang, J.M. Sohn, The effect of addition of Ca, K and Mn over $\mathrm{Ni}$-based catalyst on steam reforming of toluene as model tar compound, Catal. Today 265 (2016) 95-102.

[9] J. Yang, M. Kaewpanha, S. Karnjanakom, G. Guan, X. Hao, A. Abudula, Steam reforming of biomass tar over calcined egg shell supported catalysts for hydrogen production, Int. J. Hydrogen Energ. 41 (2016) 6699-6705.

[10] S. Nakamura, S. Kitano, K. Yoshikawa, Biomass gasification process with the tar removal technologies utilizing bio-oil scrubber and char bed, Appl. Energ. 170 (2016) 186-192.

[11] S. Zhang, Y. Song, Y.C. Song, Q. Yi, L. Dong, T.T. Li, L. Zhang, J. Feng, W.Y. Li, C.-Z. $\mathrm{Li}$, An advanced biomass gasification technology with integrated catalytic hot gas cleaning. Part III: Effects of inorganic species in char on the reforming of tars from wood and agricultural wastes, Fuel 183 (2016) 177-184.

[12] Q. Huang, Y. Tang, S. Wang, Y. Chi, J. Yan, Effect of Cellulose and Polyvinyl Chloride Interactions on the Catalytic Cracking of Tar Contained in Syngas, Energ Fuel 30 (2016) 4888-4894. 
[13] Y. Shen, J. Wang, X. Ge, M. Chen, By-products recycling for syngas cleanup in biomass pyrolysis - An overview, Renew. Sust. Energ. Rev. 59 (2016) 1246-1268.

[14] S. Zhang, Q. Dong, L. Zhang, Y. Xiong, High quality syngas production from microwave pyrolysis of rice husk with char-supported metallic catalysts, Bioresour. Technol. 191 (2015) 17-23.

[15] Y. Shen, P. Zhao, Q. Shao, F. Takahashi, K. Yoshikawa, In situ catalytic conversion of tar using rice husk char/ash supported nickel-iron catalysts for biomass pyrolytic gasification combined with the mixing-simulation in fluidized-bed gasifier, Appl. Energ. 160 (2015) 808-819.

[16] Z. Min, P. Yimsiri, M. Asadullah, S. Zhang, C.-Z. Li, Catalytic reforming of tar during gasification. Part II. Char as a catalyst or as a catalyst support for tar reforming, Fuel 90 (2011) 2545-2552.

[17] Y. Wang, X. Hu, Y. Song, Z. Min, D. Mourant, T. Li, R. Gunawan, C.-Z. Li, Catalytic steam reforming of cellulose-derived compounds using a char-supported iron catalyst, Fuel Process. Technol. 116 (2013) 234-240.

[18] S. Zhang, M. Asadullah, L. Dong, H.-L. Tay, C.-Z. Li, An advanced biomass gasification technology with integrated catalytic hot gas cleaning. Part II: Tar reforming using char as a catalyst or as a catalyst support, Fuel 112 (2013) 646-653.

[19] L. Wang, Y. Hisada, M. Koike, D. Li, H. Watanabe, Y. Nakagawa, K. Tomishige, Catalyst property of Co-Fe alloy particles in the steam reforming of biomass tar and toluene, Appl. Catal. B: Environ. 121-122 (2012) 95-104.

[20] J. Yu, F.-J. Tian, M.C. Chow, L.J. McKenzie, C.-Z. Li, Effect of iron on the gasification of Victorian brown coal with steam:enhancement of hydrogen production, Fuel 85 (2006) 127-133.

[21] Z. Min, S. Zhang, P. Yimsiri, Y. Wang, M. Asadullah, C.-Z. Li, Catalytic reforming of tar during gasification. Part IV. Changes in the structure of char in the char-supported iron catalyst during reforming, Fuel 106 (2013) 858-863.

[22] L. Jiang, S. Hu, Y. Wang, S. Su, L. Sun, B. Xu, L. He, J. Xiang, Catalytic effects of inherent alkali and alkaline earth metallic species on steam gasification of biomass, Int. J. Hydrogen Energ. 40 (2015) 15460-15469.

[23] S. Hu, L. Jiang, Y. Wang, S. Su, L. Sun, B. Xu, L. He, J. Xiang, Effects of inherent alkali and alkaline earth metallic species on biomass pyrolysis at different temperatures, Bioresour. Technol. 192 (2015) 23-30.

[24] Y. Wang, X. Li, D. Mourant, R. Gunawan, S. Zhang, C.-Z. Li, Formation of Aromatic Structures during the Pyrolysis of Bio-oil, Energ. Fuel 26 (2012) 241-247.

[25] Z. Min, M. Asadullah, P. Yimsiri, S. Zhang, H. Wu, C.-Z. Li, Catalytic reforming of tar during gasification. Part I. Steam reforming of biomass tar using ilmenite as a catalyst, Fuel 90 (2011) 1847-1854.

[26] J. Xu, S. Su, Z. Sun, M. Qing, Z. Xiong, Y. Wang, L. Jiang, S. Hu, J. Xiang, Effects of steam and $\mathrm{CO} 2$ on the characteristics of chars during devolatilization in oxy-steam combustion process, Appl. Energ. 182 (2016) 20-28.

[27] X. Li, C.-Z. Li, Volatilisation and catalytic effects of alkali and alkaline earth metallic species during the pyrolysis and gasification of Victorian brown coal. Part VIII. Catalysis and changes in char structure during gasification in steam, Fuel 85 (2006) 1518-1525. 
[28] X. Li, J.-i. Hayashi, C.-Z. Li, Volatilisation and catalytic effects of alkali and alkaline earth metallic species during the pyrolysis and gasification of Victorian brown coal. Part VII. Raman spectroscopic study on the changes in char structure during the catalytic gasification in air, Fuel 85 (2006) 1509-1517.

[29] X. Li, J.-i. Hayashi, C.-Z. Li, FT-Raman spectroscopic study of the evolution of char structure during the pyrolysis of a Victorian brown coal, Fuel 85 (2006) 1700-1707.

[30] D.M. Quyn, H. Wu, J.-i. Hayashi, C.-Z. Li, Volatilisation and catalytic effects of alkali and alkaline earth metallic species during the pyrolysis and gasification of Victorian brown coal. Part IV. Catalytic effects of $\mathrm{NaCl}$ and ion-exchangeable $\mathrm{Na}$ in coal on char reactivity, Fuel 82 (2003) 587-593.

[31] M. Garcia-Perez, X.S. Wang, J. Shen, M.J. Rhodes, F. Tian, W.-J. Lee, H. Wu, C.-Z. Li, Fast Pyrolysis of Oil Mallee Woody Biomass: Effect of Temperature on the Yield and Quality of Pyrolysis Products, Ind. Eng. Chem. Res. 47 (2008) 1846-1854.

[32] T. Nordgreen, T. Liliedahl, K. Sjöström, Elemental Iron as a Tar Breakdown Catalyst in Conjunction with Atmospheric Fluidized Bed Gasification of Biomass: A Thermodynamic Study, Energ. Fuel 20 (2006) 890-895.

[33] T. Nordgreen, T. Liliedahl, K. Sjöström, Metallic iron as a tar breakdown catalyst related to atmospheric, fluidised bed gasification of biomass, Fuel 85 (2006) 689-694. [34] S.S. Tamhankar, K. Tsuchiya, J.B. Riggs, Catalytic cracking of benzene on iron oxide-silica: catalyst activity and reaction mechanism, Appl. Catal. 16 (1985) 103-121. [35] S. Zhang, Z. Min, H.-L. Tay, M. Asadullah, C.-Z. Li, Effects of volatile-char interactions on the evolution of char structure during the gasification of Victorian brown coal in steam, Fuel 90 (2011) 1529-1535.

[36] Y. Song, Y. Wang, X. Hu, S. Hu, J. Xiang, L. Zhang, S. Zhang, Z. Min, C.-Z. Li, Effects of volatile-char interactions on in situ destruction of nascent tar during the pyrolysis and gasification of biomass. Part I. Roles of nascent char, Fuel 122 (2014) 60-66.

[37] Y. Song, Y. Wang, X. Hu, J. Xiang, S. Hu, D. Mourant, T. Li, L. Wu, C.-Z. Li, Effects of volatile-char interactions on in-situ destruction of nascent tar during the pyrolysis and gasification of biomass. Part II. Roles of steam, Fuel 143 (2015) 555-562.

[38] D.M. Keown, J.-i. Hayashi, C.-Z. Li, Effects of volatile-char interactions on the volatilisation of alkali and alkaline earth metallic species during the pyrolysis of biomass, Fuel 87 (2008) 1187-1194. 
Table 1. The properties of the component coal and biomass.

\begin{tabular}{|c|c|c|}
\hline Sample & Zhundong coal & $\begin{array}{c}\text { Acid washed rice } \\
\text { Straw [22] }\end{array}$ \\
\hline \multicolumn{3}{|c|}{ Proximate Analysis (wt \%, air-dried basis) } \\
\hline Moisture & 12.47 & 6.22 \\
\hline Volatile matter & 25.78 & 72.46 \\
\hline Fixed carbon & 57.11 & 14.05 \\
\hline Ash & 4.64 & 7.28 \\
\hline \multicolumn{3}{|c|}{ Ultimate Analysis (wt \%, dry and ash free basis) } \\
\hline $\mathrm{C}$ & 74.13 & 47.93 \\
\hline $\mathrm{H}$ & 5.18 & 6.17 \\
\hline $\mathrm{O}^{*}$ & 19.64 & 44.88 \\
\hline $\mathrm{N}$ & 0.55 & 0.91 \\
\hline S & 0.49 & 0.12 \\
\hline \multicolumn{3}{|c|}{ Ash Composition (wt \%, normalized) } \\
\hline $\mathrm{Na}_{2} \mathrm{O}$ & 6.02 & 0.23 \\
\hline $\mathrm{MgO}$ & 6.51 & 0.52 \\
\hline $\mathrm{Al}_{2} \mathrm{O}_{3}$ & 7.75 & 0.63 \\
\hline $\mathrm{SiO}_{2}$ & 17.22 & 94.01 \\
\hline $\mathrm{P}_{2} \mathrm{O}_{5}$ & 0.97 & 1.06 \\
\hline $\mathrm{SO}_{3}$ & 13.49 & 0.86 \\
\hline $\mathrm{K}_{2} \mathrm{O}$ & 0.57 & 0.73 \\
\hline $\mathrm{CaO}$ & 39.79 & 0.51 \\
\hline $\mathrm{TiO}_{2}$ & 0.64 & 0.16 \\
\hline $\mathrm{MnO}$ & 0.06 & 0.20 \\
\hline $\mathrm{Fe}_{2} \mathrm{O}_{3}$ & 6.96 & 1.08 \\
\hline
\end{tabular}

*: by difference. 
Table 2. BET surface area of fresh and spent catalysts.

\begin{tabular}{|c|c|c|c|c|c|c|c|}
\hline \multirow{4}{*}{ Atmosphere } & \multirow{4}{*}{ Samples } & \multicolumn{6}{|c|}{ BET surface area $/ \mathrm{m}^{2} / \mathrm{g}$} \\
\hline & & \multicolumn{6}{|c|}{ Fe load level } \\
\hline & & \multicolumn{3}{|c|}{$1 \mathrm{wt} \%$} & \multicolumn{3}{|c|}{$3 w t \%$} \\
\hline & & $700^{\circ} \mathrm{C}$ & $800^{\circ} \mathrm{C}$ & $900^{\circ} \mathrm{C}$ & $700^{\circ} \mathrm{C}$ & $800^{\circ} \mathrm{C}$ & $900^{\circ} \mathrm{C}$ \\
\hline \multirow[b]{2}{*}{$\mathrm{O}_{2}$} & Fresh catalysts & 343.1 & 357.4 & 359.3 & 338.9 & 375.1 & 358.6 \\
\hline & Spent catalysts & 12.4 & 13.1 & 14.9 & 10.8 & 19.5 & 9.7 \\
\hline \multirow[b]{2}{*}{$\mathrm{CO}_{2}$} & Fresh catalysts & 305.8 & 366.7 & 473.6 & 299.4 & 376.1 & 459.5 \\
\hline & Spent catalysts & 4.2 & 4.1 & 24.2 & 3.9 & 5.6 & 27.3 \\
\hline \multirow{2}{*}{ Steam } & Fresh catalysts & 406.7 & 434.3 & 479.1 & 409.3 & 447.6 & 467.5 \\
\hline & Spent catalysts & 8.6 & 77.1 & 89.7 & 5.4 & 65.3 & 82.4 \\
\hline
\end{tabular}


Table 3. Crystal size in the fresh and spent catalysts (obtained by using Scherrer equation).

\begin{tabular}{|c|c|c|c|c|c|c|c|}
\hline \multirow{4}{*}{ Atmosphere } & \multirow{4}{*}{ Samples } & \multicolumn{6}{|c|}{ Crystal size/nm } \\
\hline & & \multicolumn{6}{|c|}{ Fe load level } \\
\hline & & \multicolumn{3}{|c|}{$1 \mathrm{wt} \%$} & \multicolumn{3}{|c|}{$3 \mathrm{wt} \%$} \\
\hline & & $700^{\circ} \mathrm{C}$ & $800^{\circ} \mathrm{C}$ & $900^{\circ} \mathrm{C}$ & $700^{\circ} \mathrm{C}$ & $800^{\circ} \mathrm{C}$ & $900^{\circ} \mathrm{C}$ \\
\hline \multirow[b]{2}{*}{$\mathrm{O}_{2}$} & Fresh catalysts & 19 & 20 & 23 & 23 & 19 & 23 \\
\hline & Spent catalysts & 22 & 24 & 26 & 29 & 26 & 26 \\
\hline \multirow[b]{2}{*}{$\mathrm{CO}_{2}$} & Fresh catalysts & 30 & 28 & 32 & 30 & 31 & 29 \\
\hline & Spent catalysts & 28 & 29 & 31 & 30 & 31 & 30 \\
\hline \multirow{2}{*}{ Steam } & Fresh catalysts & 31 & 27 & 25 & 30 & 29 & 24 \\
\hline & Spent catalysts & 29 & 25 & 20 & 28 & 27 & 22 \\
\hline
\end{tabular}




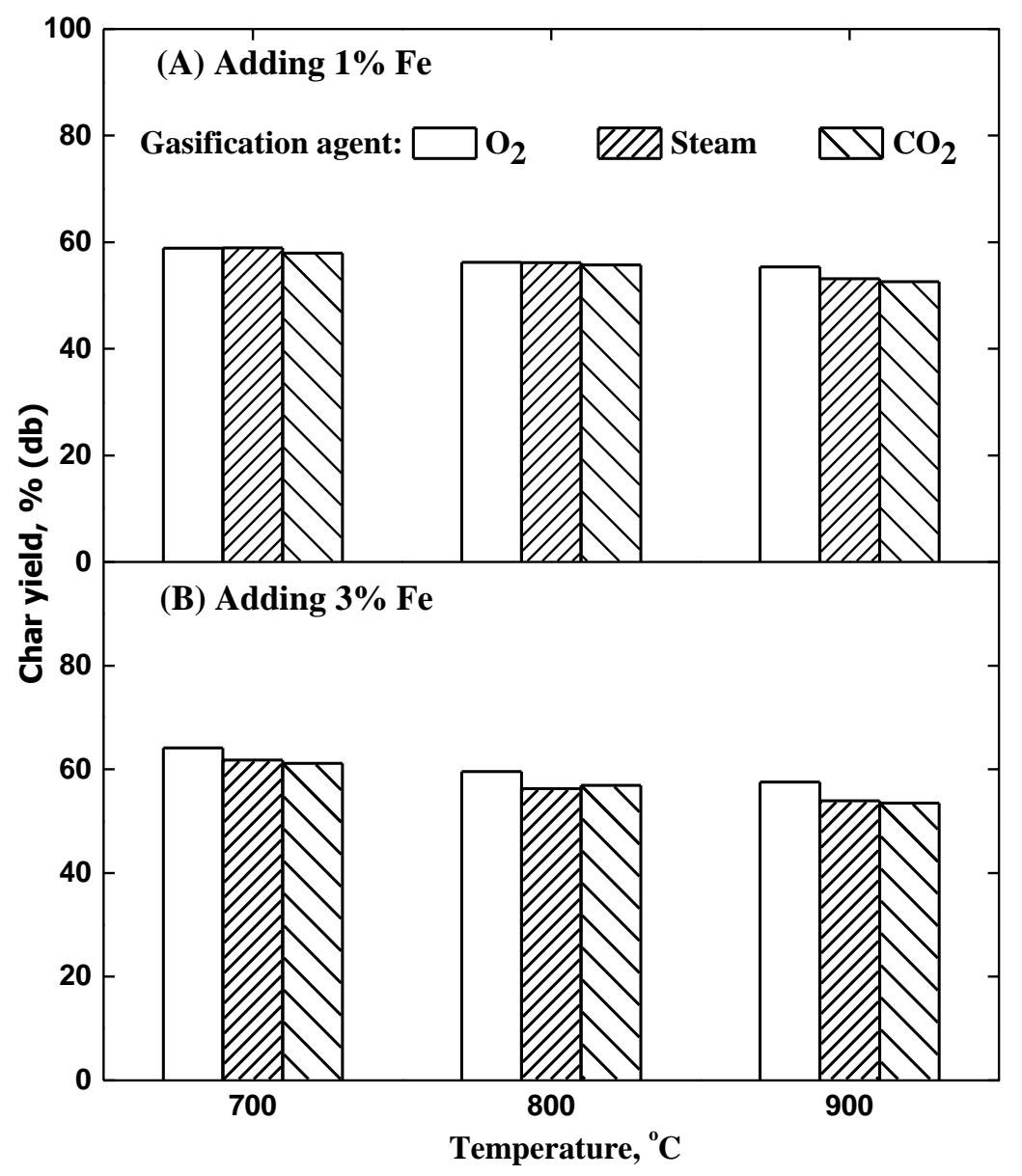

Figure 1. Char yields as a function of temperature under different gasification agents. a) using 1\% Fe-loaded coal; b) using 3\% Fe-loaded coal. 


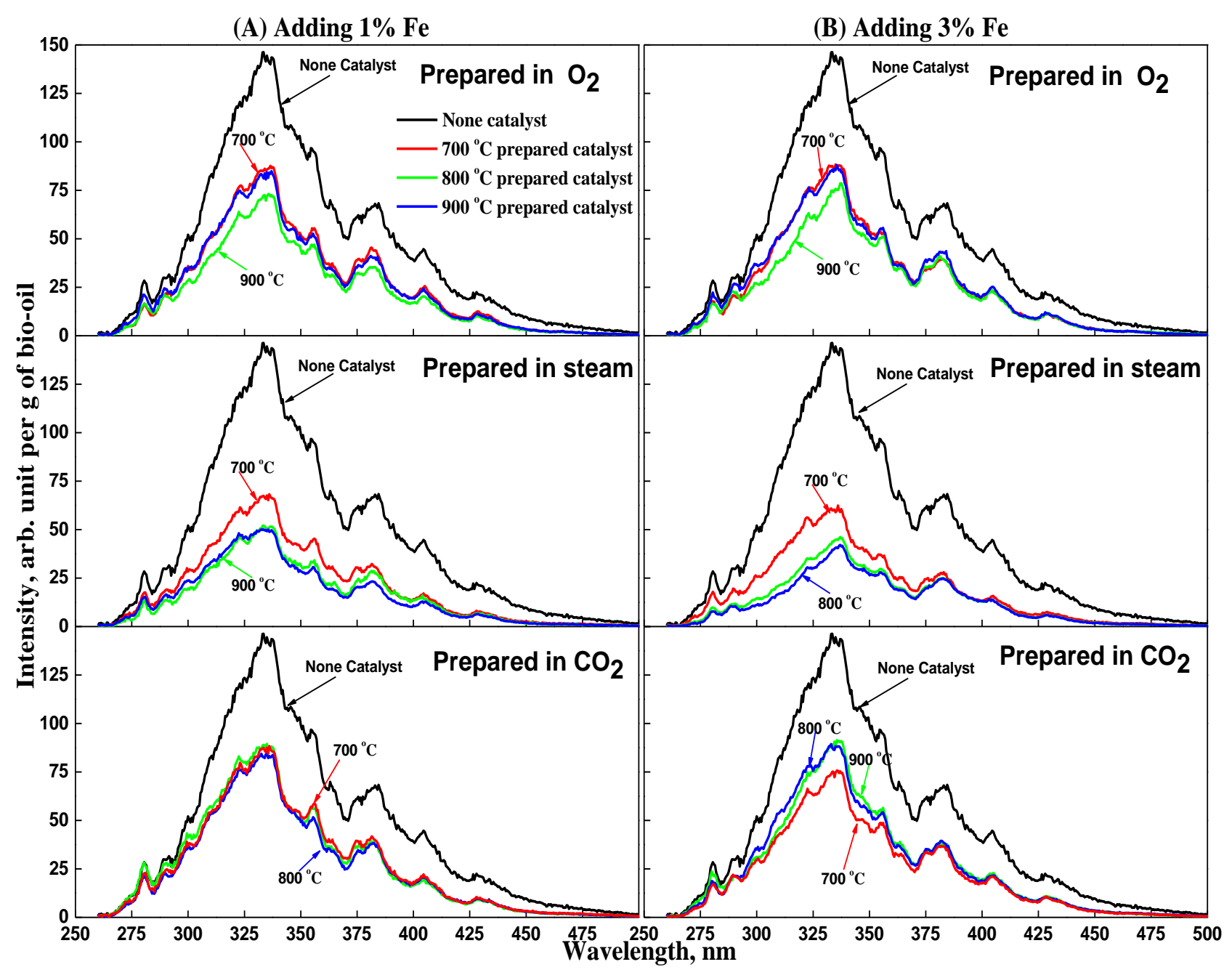

Figure 2. Constant energy $\left(-1400 \mathrm{~cm}^{-1}\right)$ synchronous spectra of tars solution produced from $800^{\circ} \mathrm{C}$ steam reforming of bio-oil with different catalysts. The condition for preparing the catalyst was indicated in each sub-figure. 
(A) Adding 1\% Fe

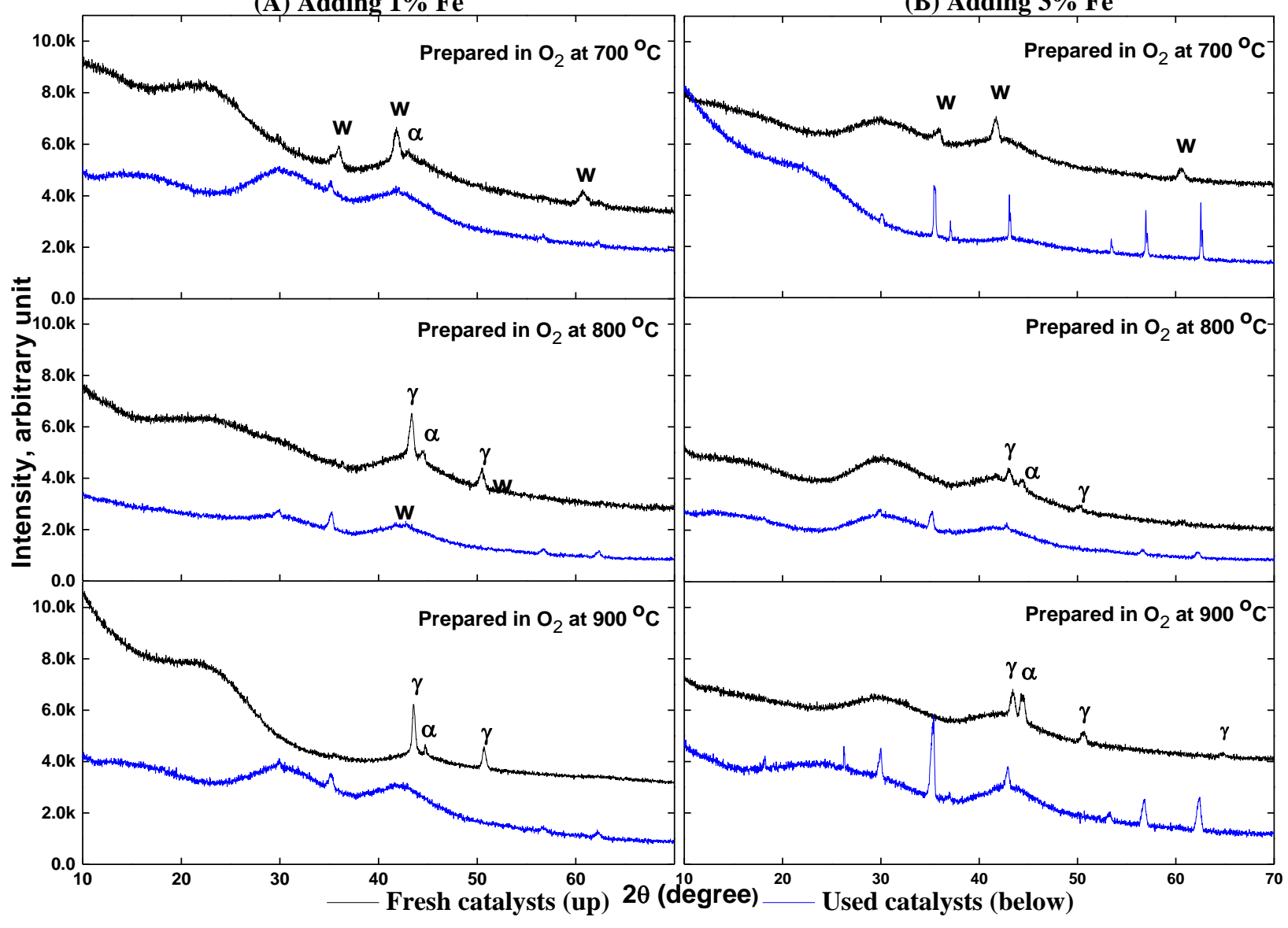

Figure 3. XRD spectra of the fresh and spent catalysts prepared from the gasification in 0.15 vol. $\% \mathrm{O}_{2}$ of $1 \%$ and $3 \%$ Fe loaded Zhundong coal at $700{ }^{\circ} \mathrm{C}, 800{ }^{\circ} \mathrm{C}$ and $900{ }^{\circ} \mathrm{C}$. M: magnetite $\mathrm{Fe}_{3} \mathrm{O}_{4}$ (peaks not labelled), $\mathrm{W}$ : wustite $\mathrm{FeO}, \mathrm{\gamma}$ : $\mathrm{\text {-Fe, }}$, a: $\mathrm{a}-\mathrm{Fe}$. 


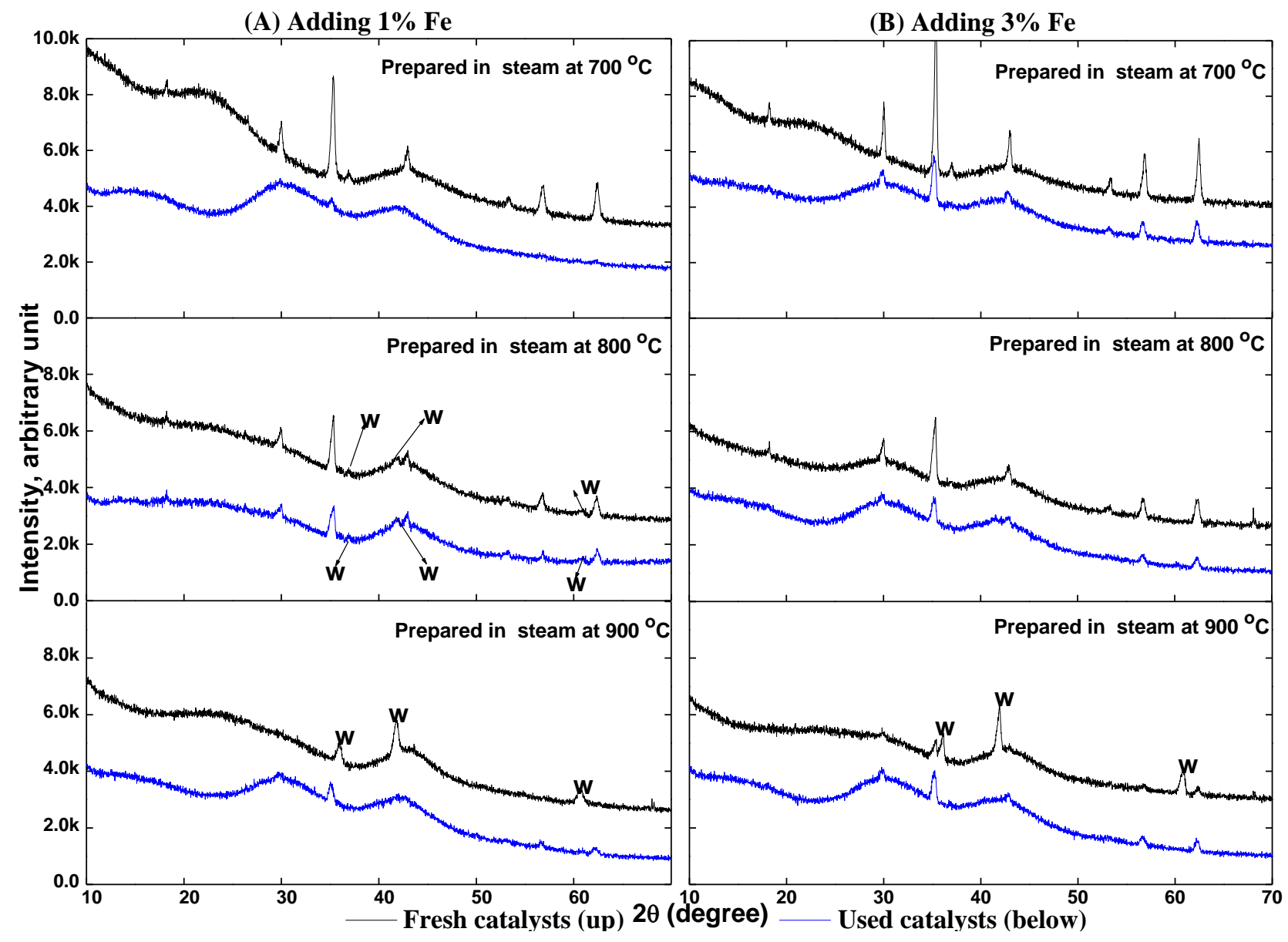

Figure 4. XRD spectra of the fresh and spent catalysts prepared from the gasification in steam of $1 \%$ and $3 \%$ Fe-loaded Zhundong coal at $700{ }^{\circ} \mathrm{C}, 800^{\circ} \mathrm{C}$ and $900{ }^{\circ} \mathrm{C}$. M: magnetite $\mathrm{Fe}_{3} \mathrm{O}_{4}$ (peaks not labelled), W: wustite FeO. 


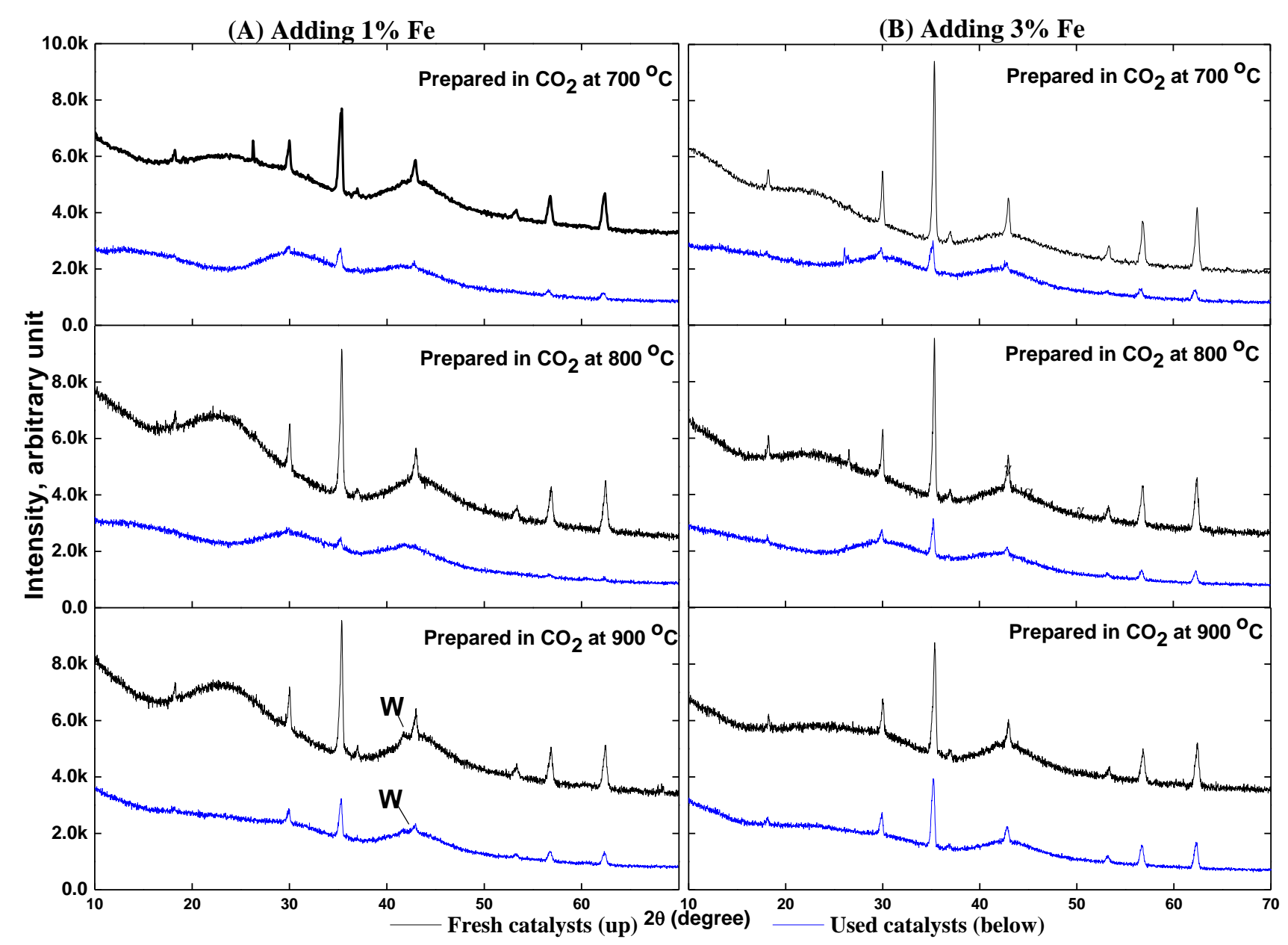

Figure 5. XRD spectra of the fresh and spent catalysts prepared from the gasification in $\mathrm{CO}_{2}$ of $1 \%$ and $3 \%$ Fe-loaded Zhundong coal at $800{ }^{\circ} \mathrm{C}$ and $900{ }^{\circ} \mathrm{C}$.M: magnetite $\mathrm{Fe}_{3} \mathrm{O}_{4}$ (peaks not labelled), W: wustite FeO. 
(A) Adding 1\% Fe

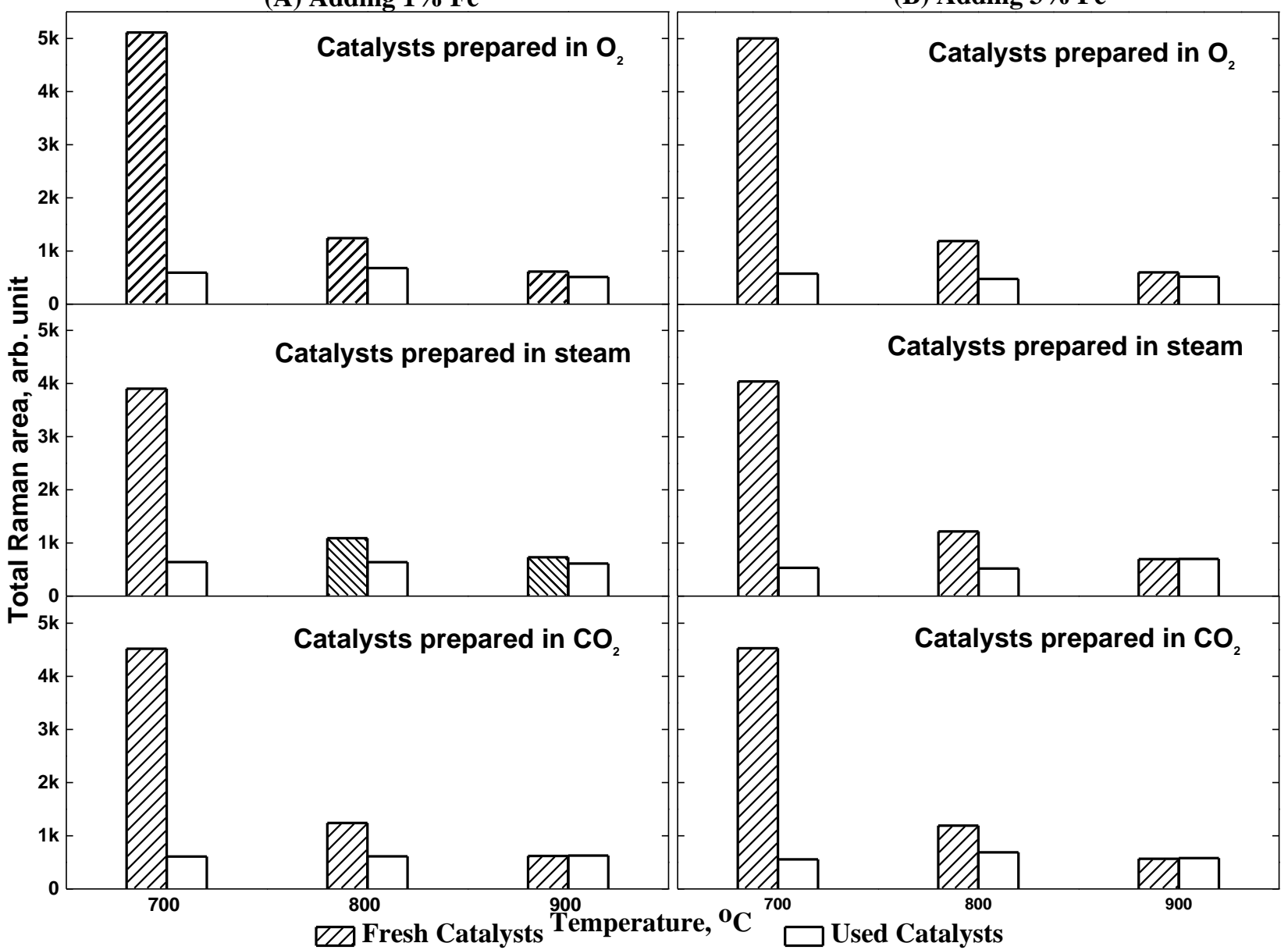

Figure 6. Total observed Raman peak area (intensity) of the fresh and used catalysts between $800 \mathrm{~cm}^{-1}$ and $1800 \mathrm{~cm}^{-1}$. The condition for preparing the catalyst was indicated in each sub-figure. 


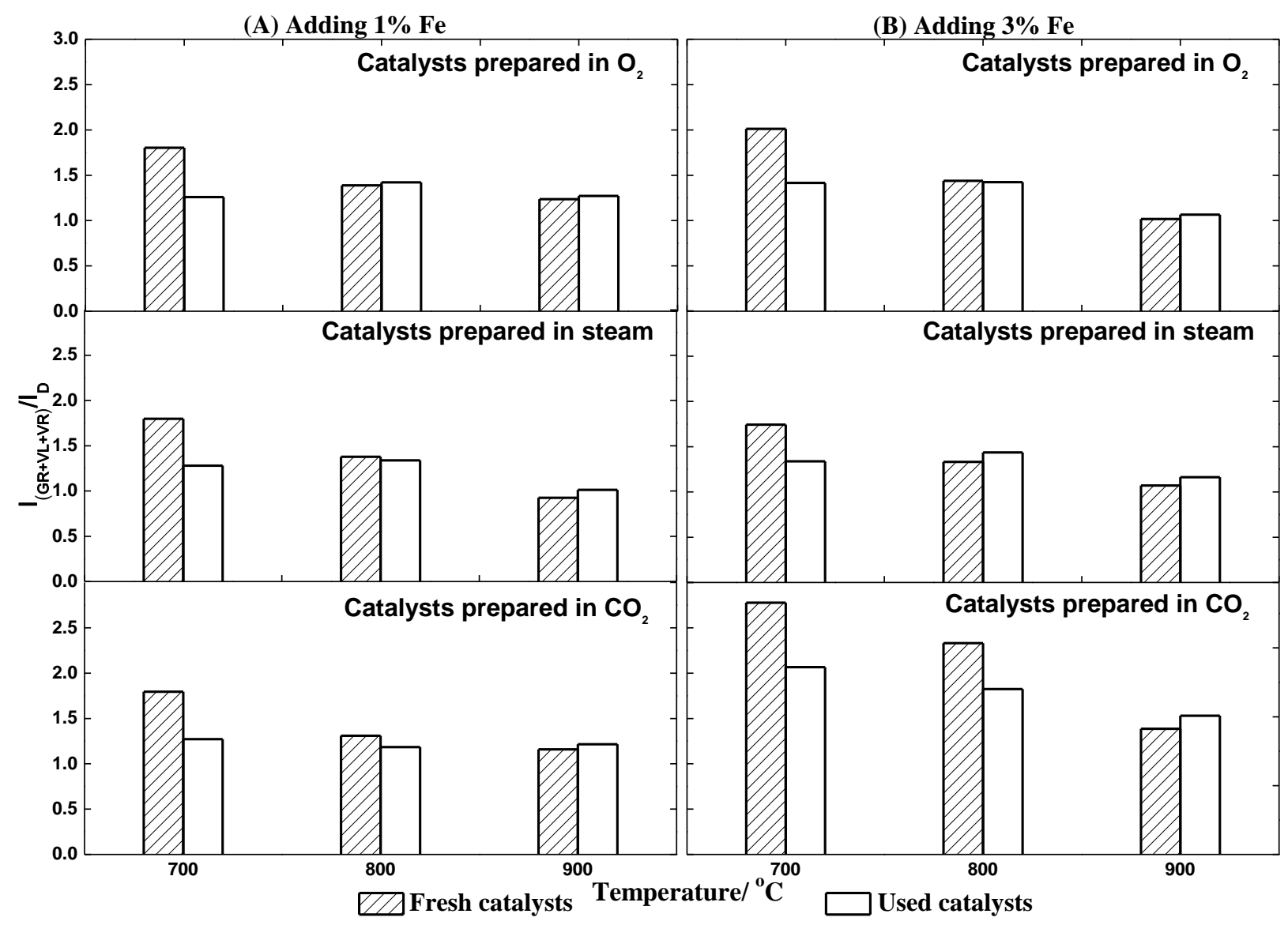

Figure 7. The ratio of band areas $I\left(G_{R}+V_{L}+V_{R}\right) / I D$ for the fresh and spent catalysts. The condition for preparing the catalyst was indicated in each sub-figure. 


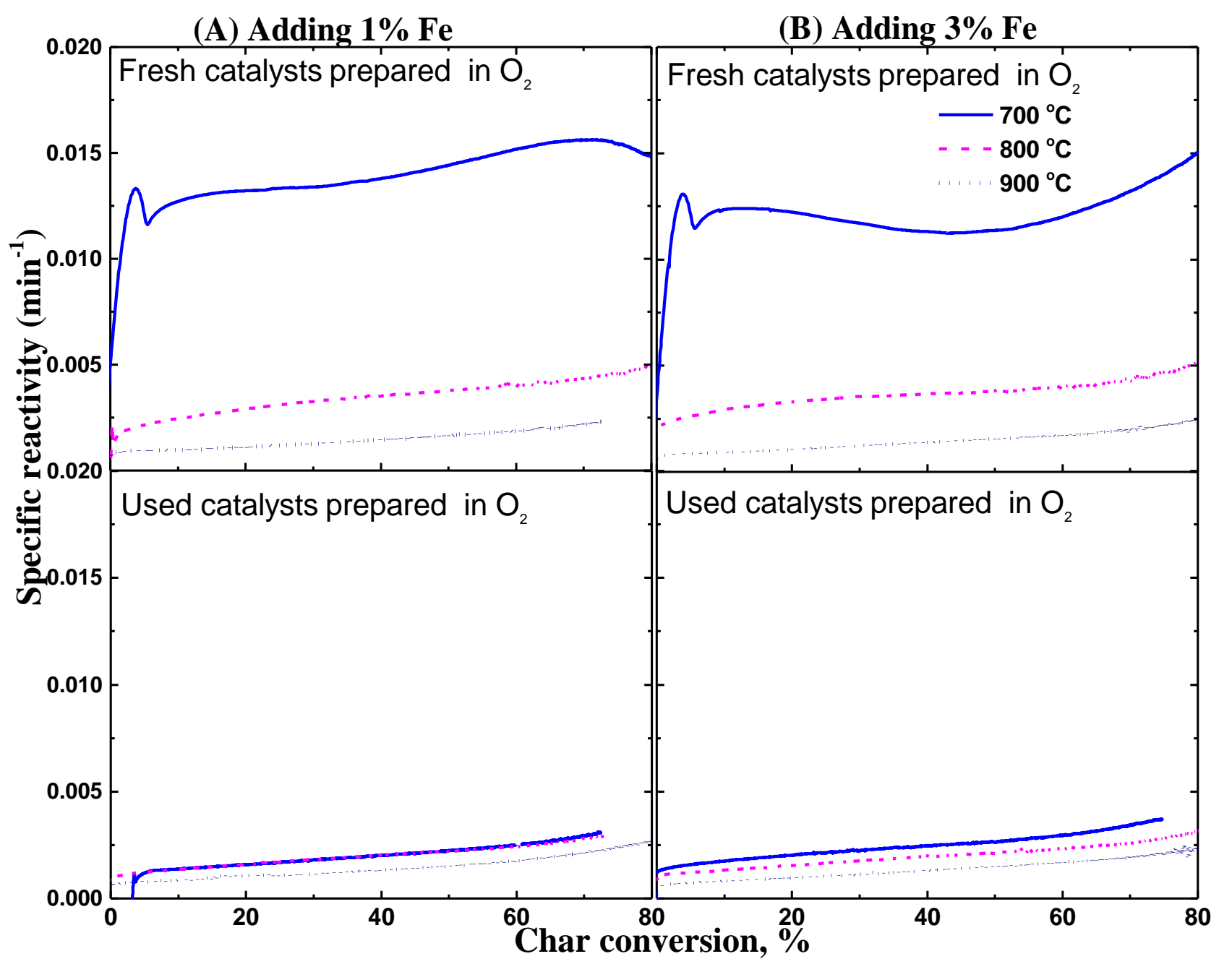

Figure 8. Catalysts specific reactivity before and after reforming experiments prepared from gasification in 0.15 vol. $\% \mathrm{O}_{2}$. 


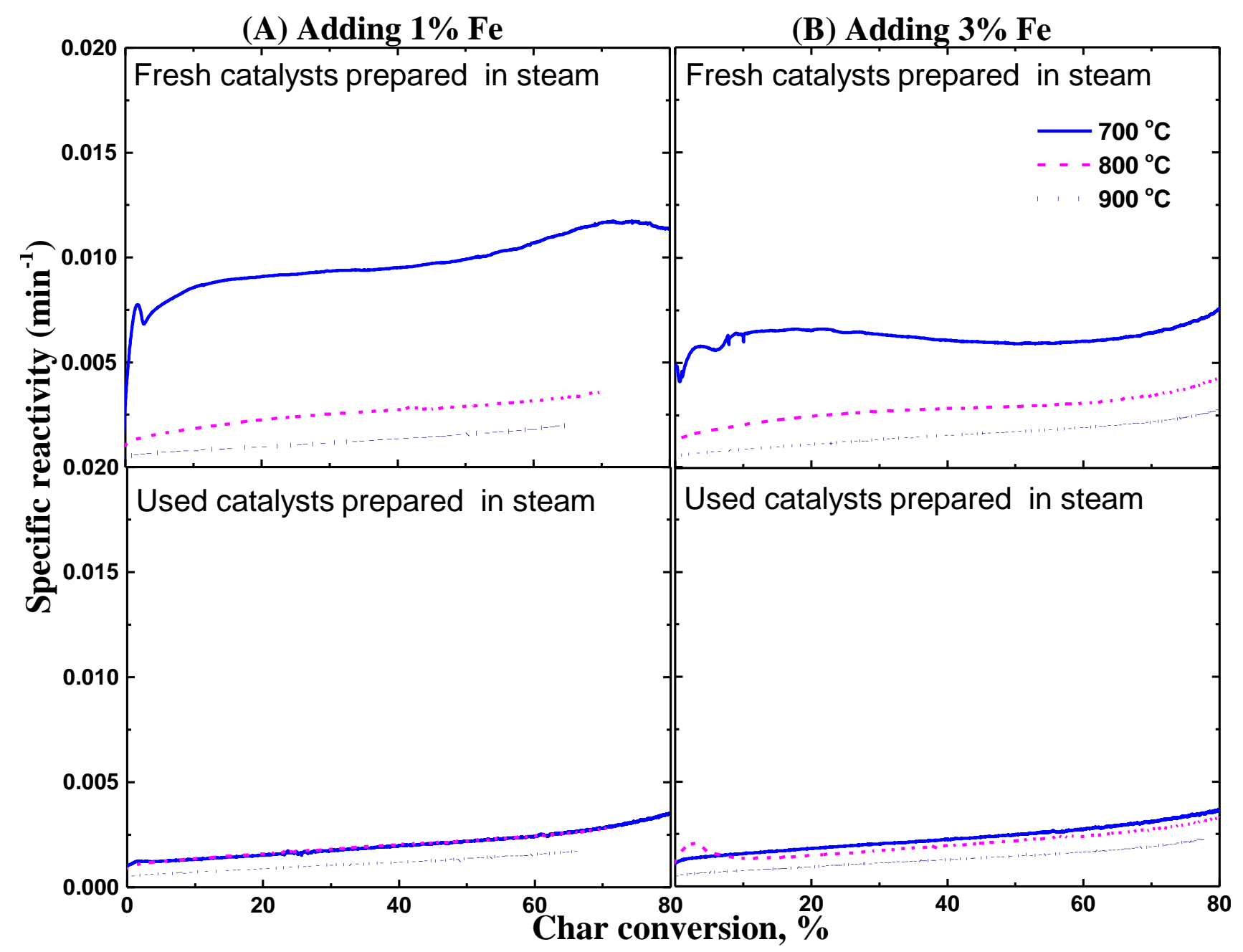

Figure 9. Catalysts specific reactivity before and after reforming experiments prepared from gasification in steam. 


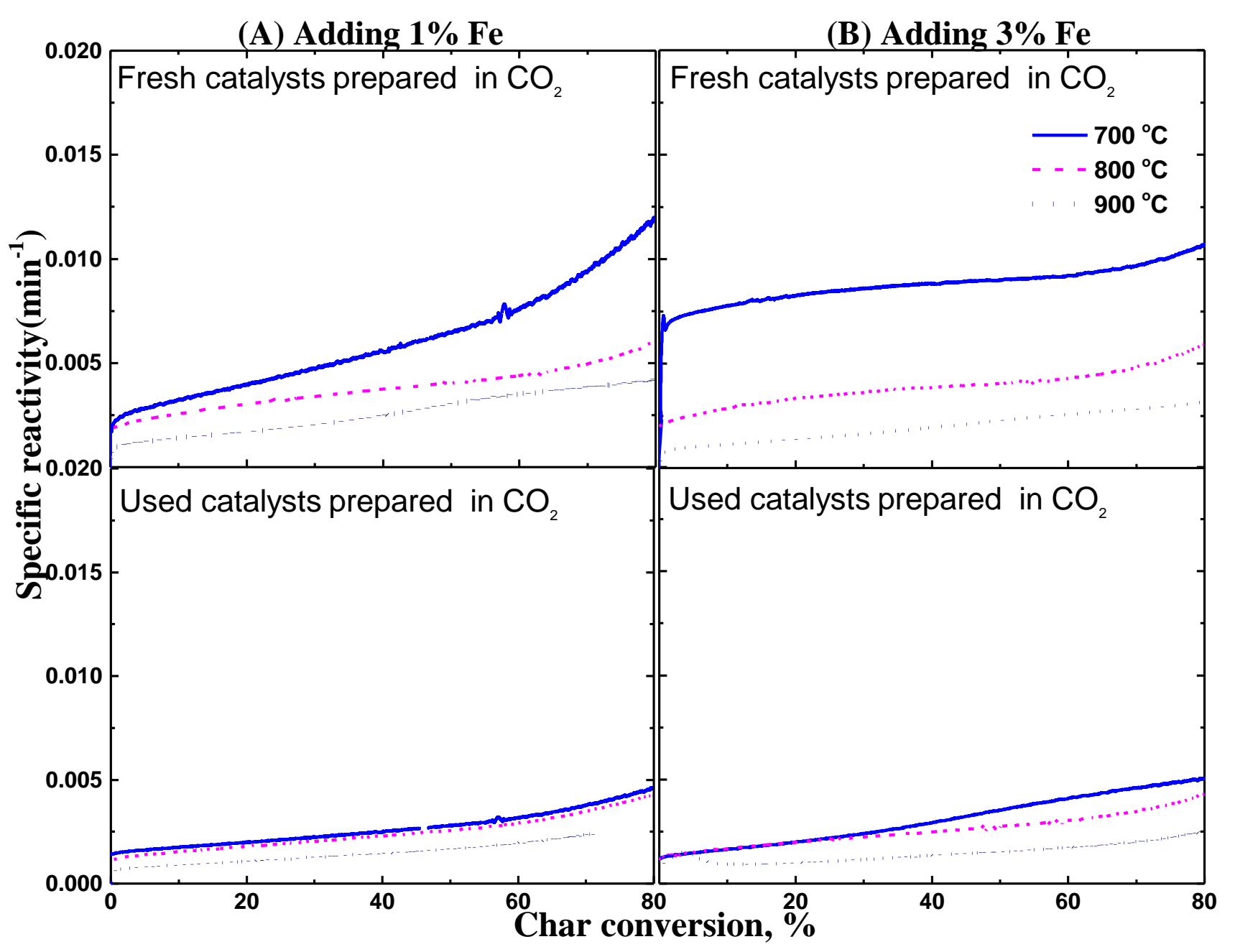

Figure 10. Catalysts specific reactivity before and after reforming experiments prepared from gasification in $\mathrm{CO}_{2}$. 